\title{
Constitutional Pluralism and Authoritarianism
}

\author{
Matej Avbelj (iD)*
}

(Received 04 July 2020; accepted 07 July 2020)

\begin{abstract}
This article examines the relationship between constitutional pluralism and authoritarianism. It does so since the Weiss decision of the FCC spurred unusual attacks on constitutional pluralism. This particular theoretical vision of European integration has been described as inherently dangerous and its abandonment has been called for out of chiefly instrumentalist reasons, in order to prevent constitutional pluralism turning into an autocrats' refuge. The article argues this critique of constitutional pluralism does not succeed. Due to its truncated, exclusively positivist understanding of constitutional pluralism, it has failed to take into account pluralism's normative core. The latter presents itself an antipode to authoritarianism, which means that the autocratic regimes simply cannot credibly avail themselves of the theory of constitutional pluralism to justify their authoritarian actions.
\end{abstract}

Keywords: constitutional pluralism; principled legal pluralism; primacy; German Federal Constitutional Court; ECB

\section{A. Introduction}

On May 5, 2020, the German Federal Constitutional Court (hereinafter: the FCC) handed down a decision in the Weiss case. ${ }^{1}$ The FCC ruled that the European Central Bank by not taking sufficiently into account the principle of proportionality in the exercise of its monetary competences within the Public Sector Purchase Programme (PSPP) exceeded its powers under the Treaties and hence acted ultra vires. Furthermore, the decision of the Court of Justice of the European Union (hereinafter: the CJEU), which due to the overly deferential review and justification that was 'not comprehensible and objectively arbitrary'2 failed to hold the ECB responsible for its alleged breach of competences, was declared ultra vires too. ${ }^{3}$ For the first time in history, the FCC thus decided that the institutions of the European Union surpassed the limits of their competences and rendered the ruling of the Union's Court in Germany ineffective. In so doing, the FCC openly and deliberately deviated from the principle of primacy of EU law and hence put an obstacle in place of the uniform and effective application of EU law that the principle of primacy ought to secure.

After a long time, in which the constitutional relationship between EU law and national law has been overshadowed by more immediate concerns of economic, security, humanitarian and

\footnotetext{
${ }^{*}$ Professor of European Law, New University, Slovenia. The research for this paper has benefited from the support of the Slovenian Research Agency within the framework of the research project No. J5-1791 (A) »An integral theory on the future of the European Union."

${ }^{1}$ Bundesverfassungsgericht [BVerfG] [Federal Constitutional Court], Case No. 2 BvR 859/15, para. 127 (May 5, 2020), http://www.bverfg.de/e/rs20200505_2bvr085915en.html [hereinafter PSPP Judgement].

${ }^{2} I d$. at para. 118 .

${ }^{3} I d$. at para. 119 .
}

(C) The Author(s), 2020. Published by Cambridge University Press on behalf of the German Law Journal. This is an Open Access article, distributed under the terms of the Creative Commons Attribution licence (http://creativecommons.org/licenses/by/4.0/), which permits unrestricted re-use, distribution, and reproduction in any medium, provided the original work is properly cited. 
political crises, the question of the ultimate arbiter of constitutionality was suddenly back. ${ }^{4}$ Moreover, the question that has long been regarded as being exclusively of a theoretical concern, which could be safely relegated to the overly abstract theoretical debates on the legal nature of European integration, has now materialised itself as a real and present practical danger for the viability of the European legal order and hence of the integration as such. ${ }^{5}$ The FCC that has long acted as an avant-garde of national constitutional courts, as a bulwark against the unconditional supremacy of EU law, now, after several decades of shots over the bow, of barking, but not biting, ${ }^{6}$ indeed carried out the ultra vires review, stripping the contested judgment of the CJEU of its legal effects in Germany. The problem was aggravated not only due to the fact that an act of EU law was declared ultra vires, admittedly and in all truth, the Czech Constitutional Court ${ }^{7}$ and the Danish Supreme Court ${ }^{8}$ had declined to follow the decisions of the CJEU before, but in particular since this was done by the most influential constitutional court of the most powerful member state of the European Union.

The political, institutional and above all academic reactions ${ }^{9}$ to the ruling have therefore been understandably vigorous. Without repeating them in great detail here, they have essentially consisted of three different, albeit not entirely unrelated, strands of arguments. One strand focused chiefly on the ultimate arbiter of constitutionality in Europe, insisting that it is high time this question was resolved, once and for all, in favour of the CJEU. ${ }^{10}$ The second strand of reactions was more nuanced, looking more broadly into how to address and resolve this specific situation, ideally, in a constructive manner. They have thus, first, pondered on whether to initiate the infringement procedure against Germany or not, ${ }^{11}$ and, secondly, they have put forward (old) proposals of creating a special mixed EU-national tribunal that could, to the satisfaction of supranational and national constitutional authorities, square the circle of the contentious Kompetenz-Kompetenz issue in EU law. ${ }^{12}$ Finally, the third strand of reactions concentrated mainly on the consequences of this particular German ruling for the European Union. While the concerns have been, of course, also legal, related to the potential undermining of the constitutional foundations of EU legal order, ${ }^{13}$ they have foremost stressed the policy as well as political consequences of this ultra vires ruling. It has been thus argued that the ruling comes at the wrong

\footnotetext{
${ }^{4}$ Mattias Kumm, Who is the Final Arbiter of Constitutionality in Europe?: Three Conceptions of the Relationship between the German Federal Constitutional Court and the European Court of Justice and the fate of the European market order for bananas, 36 Common MKt. L. Rev. 351 (1999).

${ }^{5}$ Sarmiento and Weiler have stressed that »the profound damage to the integrity of the EU's legal order and its rule of law cannot be overstated. Daniel Sarmiento \& Joseph H.H. Weiler, The EU Judiciary After Weiss: Proposing A New Mixed Chamber of the Court of Justice, VerfassungsbloG, (2 June 2020), https://verfassungsblog.de/the-eu-judiciary-after-weiss/.

${ }^{6}$ Christoph U. Schmid, All Bark and No Bite: Notes on the Federal Constitutional Court's 'Banana Decision', 7 EuR. L.J. 95-113 (2001).

${ }^{7} \mathrm{Pl}$. ÚS 5/12, Slovak Pensions, Czech Constitutional Court case of 31 January 2012; English translation available at: http:// www.usoud.cz/en/decisions/20120131-pl-us-512-slovak-pensions/.

${ }^{8}$ Court of Justice: Judgment of 19 April 2016, Case No. C-441/14, Dansk Industri (on behalf of Ajos A/S) v. Estate of Karsten Eigil Rasmussen [GC] (Den).

${ }^{9}$ For a detailed overview of these reactions, see Daniel Sarmiento, Requiem for Judicial Dialogue - The German Federal Constitutional Court's judgment in the Weiss case and its European implications, 16 EU LAW LIVE 9 (2020); Heiko Sauer, Substantive EU Law Review Beyond the Veil of Democracy: The German Federal Constitutional Court Ultimately Acts as Supreme Court of the EU, 16 EU LAW LIVE 2 (2020).

${ }^{10}$ Federico Fabbrini, Suing the BVerfG, VerfassungsbloG, (13 May 2020), https://verfassungsblog.de/suing-the-bverfg/; Daniel R. Kelemen et al., National Courts Cannot Override CJEU Judgments: A Joint Statement in Defense of the EU Legal Order, VerfassungsbloG, (26 May 2020), https://verfassungsblog.de/national-courts-cannot-override-cjeu-judgments/.

${ }^{11}$ Christoph Möllers, Sollte die EU-Kommission Deutschland wegen des Karlsruher Ultra-Vires-Urteils verklagen? CONTRA, Verfassungsblog, (16 May 2020), https://verfassungsblog.de/sollte-die-eu-kommission-deutschland-wegendes-karlsruher-ultra-vires-urteils-verklagen-contra/; Ingolf Pernice, Sollte die EU-Kommission Deutschland wegen des Karlsruher Ultra-Vires-Urteils verklagen? PRO, VerfassunGSBLOG, (16 May 2020), https://verfassungsblog.de/sollte-die-eukommission-deutschland-wegen-des-karlsruher-ultra-vires-urteils-verklagen-pro/.

${ }^{12}$ Sarmiento \& Weiler supra note 5.

${ }^{13}$ Franz C. Mayer, Auf dem Weg zum Richterfaustrecht?: Zum PSPP-Urteil des BVerfG, VerfassungsBlOG, (7 May 2020), https://verfassungsblog.de/auf-dem-weg-zum-richterfaustrecht/.
} 
time and that it might empower the wrong people. ${ }^{14}$ Not only does the FCC decision, by questioning its legal foundations, undermine the Public Sector Purchase Programme (PSPP) of the $\mathrm{ECB}$, it also threatens the even more comprehensive Corona package, which is indispensable for coping with the economic downturn caused by the epidemics. ${ }^{15}$ Furthermore, the FCC act of judicial disobedience could be used as a factor of legitimation for a similar rejection of the unpopular CJEU rulings by the constitutional courts in the (proto-)authoritarian regimes in Central and Eastern Europe. ${ }^{16}$ If the ultra vires review of EU law can be conducted by the most powerful constitutional court in Europe, this must be permitted, lest to be guilty of double standards, to all other constitutional courts, too. ${ }^{17}$

It is this domino effect argument that the present contribution would like to engage with, however, not on the level of likelihood that the so-called captured constitutional courts would indeed follow the FCC in practice, but rather by examining the theoretical rationale for potentially doing so. It is clearly one of the most unusual features of the present academic critical reactions to the FCC ruling that they have blamed it on a particular theory of EU constitutional law, namely on constitutional pluralism. In the aftermath of the Weiss ruling, a group of EU law scholars published a manifesto against those versions of constitutional pluralism "that would defend the authority of FCC or any national court to make such a ruling and that helped (even if unintentionally) encourage it to do so." ${ }^{18}$ However, the critique did not stop just there, it went further by claiming that it was not only predictable, it had in fact already been predicted that the autocratic governments and their captured courts would have used constitutional pluralism to override, in their eyes, unfavorable rulings of the CEJU. ${ }^{19}$ In other words, since the academic theory of constitutional pluralism has or still could become the autocrats' refuge, the academia should approach it with caution or, even better, dismantle it; ${ }^{20}$ its descriptive and analytical, as well as - perhaps in normal times at least - normative appeal notwithstanding.

This conclusion, which appears to be gaining traction in the European scholarly community, ${ }^{21}$ certainly begs the question of the rapport between constitutional pluralism and authoritarianism. Is it really true that constitutional pluralism can facilitate authoritarian tendencies in the European Union by providing the perpetrators with justification, theoretical scholarly defense of their actions against the EU institutions as these are trying to restore the rule of law and the values of constitutional democracy? This is the question that the rest of this contribution is dedicated to.

\section{B. Constitutional Pluralism}

In answering the question of constitutional pluralism as a facilitator of authoritarianism, one must first reflect on the nature of the argument being made about the rapport between constitutional pluralism and authoritarianism. Arguing in descriptive and presumably factually accurate terms that constitutional pluralism is being relied upon by the autocrats to justify their actions, it could namely amount to making two claims of uneven strength. First, that constitutional pluralism, like

\footnotetext{
${ }^{14}$ Karen Alter, Is it a Dance or is it Chicken?: The German Constitutional Court's European Central Bank Ruling, VERFASSUNGSBLOG, (13 May 2020), https://verfassungsblog.de/is-it-a-dance-or-is-it-chicken/.

${ }^{15}$ Miguel Maduro, Some Preliminary Remarks on the PSPP Decision of the German Constitutional Court, VERFASSUNGSBLOG, (5 May 2020), https://verfassungsblog.de/some-preliminary-remarks-on-the-pspp-decision-of-thegerman-constitutional-court/.

${ }^{16} I d$.; Daniel R. Kelemen et al., National Courts Cannot Override CJEU Judgments: A Joint Statement in Defense of the EU Legal Order, VerfassungsbloG, (26 May 2020), https://verfassungsblog.de/national-courts-cannot-override-cjeu-judgments/. ${ }^{17} I d$.

${ }^{18}$ Daniel R. Kelemen et al., National Courts Cannot Override CJEU Judgments: A Joint Statement in Defense of the EU Legal Order, VERFASSUNGSBLOG, (26 May 2020), https://verfassungsblog.de/national-courts-cannot-override-cjeu-judgments/.

${ }^{19}$ Daniel R. Kelemen \& Laurent Pech, The Uses and Abuses of Constitutional Pluralism: Undermining the Rule of Law in the Name of Constitutional Identity in Hungary and Poland, 21 Cambridge Yearbook Eur. Leg. Stud. 59 (2019).

${ }^{20} I d$. at 74 .

${ }^{21}$ Kelemen et al., supra note 18.
} 
any other theory or idea, is being used contrary to its object and purpose by the autocrats. ${ }^{22}$ Second, that constitutional pluralism, unlike other theories and ideas, is conceptually, due to its very ideational structure, susceptible to the use by the autocrats. The first claim is, obviously, much more modest and therefore also much less interesting. It essentially confirms a well-known fact that any theory or idea, no matter how virtuous and well-intended, can be abused. However, the second claim is much stronger and its theoretical bearing on constitutional pluralism much heavier. If constitutional pluralism is conceptually, an sich, lending itself as a tool for autocrats, this, at least indirectly, must suggest its own autocratic character, which therefore disqualifies it as a theory that a reasonable, bona fide person, let alone an expert in EU law, could subscribe to.

Indeed, it appears that it has been this second claim that has been put forward by the critics of constitutional pluralism. Already before the FCC ruling, ${ }^{23}$ and in particular after it, ${ }^{24}$ it has been thus argued that constitutional pluralism as an idea is "inherently" dangerous. ${ }^{25}$ As the critics put it bluntly: "Constitutional pluralism is a fundamentally flawed and unsustainable concept, inherently prone-alongside the closely related notion of 'constitutional identity' - to abuse by autocrats and other enemies of the rule of law." ${ }^{26}$ However, all this conceptual failure, unsustainability and autocratic malleability of constitutional pluralism would, the critics claim, be overcome by simply trading constitutional pluralism for "a more traditional understanding of the primacy of EU law - namely long developed by the CJEU in a long line of jurisprudence since Costa." ${ }^{27}$ In short, the unqualified and unconditional supremacy of EU law is a cure to any EU illness, the autocratic backsliding included.

The very simplicity of the remedy suggested begs the question of the credibility of this critique, which is weakened even further when the critique is analytically unpacked. In so doing, one cannot but notice its self-referential and circular character. Accordingly, constitutional pluralism is fundamentally flawed, because it is built on "unsustainable foundation composed of a mix of wishful thinking and evasion of tough choices." ${ }^{28}$ The unsustainability of constitutional pluralism, which is the reason of its fundamental flaws, is hence attributed to its unsustainable foundations that make constitutional pluralism fundamentally flawed in the first place. And, furthermore, constitutional pluralism is inherently prone to abuse by autocrats, not just because they can in fact abuse it, but since, as the adjective "inherently" must suggest, it is a priori flawed and unsustainable. In other words, it follows from this circular and self-referential debilitating critique of constitutional pluralism that the latter is fundamentally flawed, unsustainable and prone to autocratic abuse, because it is flawed, unsustainable and prone to autocratic abuse. To conclude, constitutional pluralism is such, because its critiques say so. But are they right? The following will claim that they are not.

As the suggested remedy for all ills of European integration in form of a monistic supremacy of EU law reveals best, the critics have a very narrow, indeed truncated understanding of constitutional pluralism. The essence of constitutional pluralism, at least as I would be willing to defend it, lies not in its positivistic, legalistic, formal determination who has the final say in a composite legal order of the European integration. To the contrary, the essence of constitutional pluralism lies in its normative core ${ }^{29}$ in its ethical value-based foundation: in the ethics of pluralism. It is the latter that justifies the non-monistic understanding of supremacy, that is primacy as a relational

\footnotetext{
${ }^{22}$ Kelemen \& Pech, supra note 19.

${ }^{23}$ Kelemen \& Pech, supra note 19.

${ }^{24}$ Kelemen et al., supra note 18.

${ }^{25}$ Kelemen \& Pech, supra note 19.

${ }^{26}$ Kelemen \& Pech, supra note 19.

${ }^{27}$ Kelemen \& Pech, supra note 19.

${ }^{28}$ Kelemen \& Pech, supra note 19 , at 62.

${ }^{29}$ I borrow the expression from Jessica Lawrence, Constitutional Pluralism's Unspoken Normative Core, 21 CAMBRIDGE YeARbook Eur. LEg. STUd. 24 (2019).
} 
principle between autonomous legal orders, ${ }^{30}$ standing for a plurality of constitutional and epistemic sites. ${ }^{31}$ If one does concentrate on this pluralist normative core of constitutional pluralism, as we do, it becomes immediately clear not only that constitutional pluralism is not fundamentally flawed, based on wishful thinking and unsustainable, but especially that constitutional pluralism cannot be portrayed as being inherently prone to abuse by autocrats. If anything, the opposite is true: pluralism is inherently not authoritarian. It is an antipode of authoritarianism. This becomes clear when one looks more closely into pluralism's normative core.

\section{Constitutional Pluralism's Normative Core}

In order to understand the normative core of constitutional pluralism, one ought to dig in its normative DNA. Constitutional pluralism as a descriptive, analytical and normative theory of the legal nature of European integration is derived from legal pluralism, which is in turn an embodiment of the philosophy of pluralism in the field of law as an example of institutional normative order. ${ }^{32}$ In other words, most theories of constitutional pluralism, ${ }^{33}$ but certainly my approach of principled legal pluralism, ${ }^{34}$ genetically depend on pluralism as a philosophy. This is then institutionalized in the law more generally as legal pluralism, ${ }^{35}$ that is, in turn, applied under the notion of constitutional pluralism to a specific example of the European Union. To grasp the normative core of constitutional pluralism, it is thus necessary to understand the essence of pluralism as a philosophy. This is, by no means, an easy task. There is simply no single philosophical definition of pluralism, but we have a pluralism of pluralisms instead. ${ }^{36}$ The choice is between a negative conception of pluralism, conceived of as a perennial conflict and hence a tragic loss for everyone involved, ${ }^{37}$ or a positive conception, which treats pluralism as an opportunity. Accordingly, and to repeat after Sartori: "Pluralism affirms the belief that diversity and dissent are values that enrich individuals as well as their polities and societies." ${ }^{38}$

Building on this positive conception of pluralism, as I have argued in more detail elsewhere, ${ }^{39}$ pluralism shall be understood as a normative framework for an ordered plurality. Plurality stands for differences and diversity, for the right to be different and to do things one's own way. Plurality is thus an expression of autonomy, first individual and then collective. Autonomy is another word for self-realisation or self-fulfilment of each and every individual as she sees fit within the context of an equal right for others. This right, however, emanates from the core value of pluralism, which is concurrently its normative point of departure and its outcome. ${ }^{40}$ This is the value of human dignity. Each and every individual has, by way of her very humanity, equal human dignity. This endows her with the said right of self-fulfilment in her own chosen way. As there are many (a plurality of) individuals, there are - as a result of respect for their equal human dignity - many (a plurality) of actual and potential ways of self-fulfilment, many conceptions of a good life.

\footnotetext{
${ }^{30}$ Matej Avbelj, Supremacy or Primacy of EU Law-(Why) Does it Matter?, 17 EUR. L.J. 744 (2011).

${ }^{31}$ Neil Walker, The Idea of Constitutional Pluralism, 65 MoD. L. REv. 317, 338 (2002).

${ }^{32}$ Neil Maccormick, Institutions of Law, An Essay in Legal Theory (2007).

${ }^{33}$ For an overview, see Matej Avbelj \& Jan Komarek, Constitutional Pluralism in the EU and Beyond (2012).

${ }^{34}$ Matej Avbelj, The European Union Under Transnational law: A Pluralist Appraisal (2018).

${ }^{35}$ For an overview, see Gareth Davies \& Matej Avbelj, Research Handbook on Legal Pluralism and EU Law (2018).

${ }^{36}$ AvbelJ, supra note 34, at 23, drawing on Ralf Michaels, Global Legal Pluralism, 5 AnNu. Rev. LAw Soc. SCI. 243 (2009).

${ }^{37}$ Victor M. Muniz-Fraticelli, The Structure of Pluralism - On the Authority of Associations 11 (2014).

${ }^{38}$ Giovanni Sartori, Understanding Pluralism, 8 J. Democracy 58 (1997).

${ }^{39}$ The following two paragraphs draw on Matej Avbelj, Pluralism and Systemic Defiance in the EU, in THE ENFORCEMENT OF EU LaW and Values: Ensuring Member States' Compliance 44-64 (András Jakab \& Dimitry Kochenov eds., 2017).

${ }^{40}$ Turkuler Isiksel, Global legal pluralism as fact and norm, 2 GLOBAL CONST. 160 (2013); who critiques pluralism for being contingent on other values and not a value in itself. While this is true, there are hardly any values which are entirely self-dependent.
} 
As humans, we therefore necessarily live in a world, which is pluralist and therefore diverse. The respect for human dignity mandates that this is good and that plurality should consequently be preserved and even fostered. However, plurality is not the same as pluralism. Pluralism is more than plurality; it is a connected plurality. ${ }^{41}$

Pluralism requires that different entities forming a plurality should be preserved by mutually recognising this right for each other, but they must simultaneously develop the normative spirit of pluralism underlined by the ethics of a dialectic open self. This is to say that the various entities forming a plurality must commit not only to the preservation of this plurality, but also to the common whole - they have to see themselves as part of the same framework, as if they were travelling in the same boat. ${ }^{42}$ Rather than social homogeneity, it is then this normative spirit of pluralism, with a monistic foundation of human dignity, which provides the fibre of cohesiveness required for the viability of any social entity no matter how tiny or small, let alone for polity building. ${ }^{43}$ In short, pluralism is understood here as a paradigm which derives from human dignity and is designed to ensure human dignity's preservation and flourishing.

Legal pluralism is a legal institutionalisation of this pluralist philosophy, while constitutional pluralism applies it as the best fitting theory to the European Union since the latter is a pluralist entity in socio-political and therefore also legal terms. In socio-political terms, the European Union is namely not a single polity, but a composition of a plurality of polities: national and supranational. These distinct political communities have the right to make their own fundamental choices within their own fundamental boundaries ${ }^{44}$ and they therefore also exist as distinct epistemic sites. ${ }^{45}$ The pluralist legal structure of the European integration, the fact that national and EU legal orders remain autonomous and independent from each other, reflects and protects this socio-political plurality inside the European Union. At the same time, it imposes two requirements on the constitutive entities of the European Union. They must be committed to pluralism: both internally and externally. Internally, the pluralist ethics of a dialectic open-self requires erecting an institutional set-up, which is based on a comprehensive system of checks and balances that prevents the monopolisation of power, its use and abuse over the individuals, over all types of societal and political minorities, indeed over all those who are different and would like to live their own particular model of a good life under the rule of law. In turn, these internally pluralist polities and legal orders must then externally engage in the same kind of a pluralist system of checks and balances between themselves with a simultaneous commitment to the pluralist common whole, e.g. to the success of the comment project of European integration, in which they partake.

As Nico Krisch, in particular, has stressed, legal pluralism due to its described characteristics acts as a normative platform for a learning process between the polities and legal orders, providing ample space for contestation and adaptation, ${ }^{46}$ engaging them in the process of constant justification that leaves little room for legal and political excesses, as well as the abuse of power. ${ }^{47}$ Consequently, legal pluralism acts as a measure of the legitimacy of the exercise of legal authority by the entities forming a plurality. ${ }^{48}$ The legitimacy of the exercise of the authority of singular

\footnotetext{
${ }^{41}$ For a distinction between pluralism and plurality, see Neil Walker, Constitutionalism and Pluralism in Global Context, in Constitutional Pluralism in the EU AND Beyond 17-38 (2012).

${ }^{42}$ See, e.g. James Tully, Strange Multiplicity: Constitutionalism in an Age of Diversity (1995); and the use of the metaphor of the Spirit of the Haida Gwaii.

${ }^{43}$ Matej Avbelj, Theory of European Union, 36 EUR. L. REv. 818 (2011).

${ }^{44}$ Joseph Weiler, Fundamental Rights and Fundamental Boundaries: On Standards and Values in the Protection of Human Rights, in The European Union and Human Rights 52 (Nanette A. Neuwahl \& Allan Rosas eds., 1998) ("Fundamental boundaries are about the autonomy and self-determination of the communities.").

${ }^{45}$ Neil Walker, The Idea of Constitutional Pluralism 65 MoD. L. Rev. 361 (2002).

${ }^{46} \mathrm{NiCO}$ KRISCH, BEYOND CONSTITUTIONALISM 228-230 (2010).

${ }^{47}$ AvBeLJ, supra note 34 , at 38-39.

${ }^{48}$ AVBELJ, supra note 34 , at 39 .
} 
entities in a pluralist setting depends on the pluralist quality of their engagement with other entities. ${ }^{49}$ In this manner, pluralism, legal pluralism and constitutional pluralism are all inherently incompatible with authoritarianism. Authoritarian philosophy is not pluralist and it does not have human dignity at its normative core. Authoritarianism is not about creating a normative learning platform, engendering contestation and adaptation, it is about imposing normative outcomes dictated by absolute, monopolised power. Authoritarianism is not about respecting plurality, difference and diversity. Authoritarianism in institutional terms does not endorse a comprehensive system of checks and balances; it aims at dismantling it in favour of a swift and as unencumbered use of power. Authoritarianism is not interested in measuring its legitimacy by exercising relative authority. Authoritarianism pursues absolute authority to be declaratorily exercised in the name of the people, but de facto in favour of those in power.

Since pluralism and authoritarianism are hence inherently different, are in fact antipodes, the instrumentalist arguments against constitutional pluralism in the EU lose their argumentative strength. ${ }^{50}$ The proto-authoritarian regimes simply cannot credibly avail themselves of constitutional pluralism to justify their deviation from EU law. As I have argued elsewhere, pluralism cannot be defied pluralistically. Relying on constitutional pluralism requires being a pluralist first. A pluralist European integration assumes that its member states are well-ordered societies ${ }^{51}$ and $a b$ initio committed to pluralism. The pluralist nature of the European Union leaves no room for pretexts for the proto-authoritarian member states. Pluralist insistence on the respect for national constitutional autonomy, for the national pluralist-self, cannot be misused or even abused to legitimate national measures corrosive of the EU fundamental values under the guise of pluralism.

\section{Different Cases of Constitutional Pluralism}

The preceding discussion has demonstrated that constitutional pluralism cannot be persuasively criticised as a facilitator of authoritarian trends in the European Union. The opposite is true. Pluralism is an antipode of authoritarianism and a measure of legitimacy that disqualifies any authoritarian attempts as illegitimate, even if and when they are ostensibly committed in the name of pluralism. The validity of this abstract claim is all the more apparent if couched in more concrete terms, by focusing on the actual cases of employing constitutional pluralism to deviate from the requirements of EU law. In this respect, there exists an important difference in kind between the FCC ruling and the potential cases penned by the captured constitutional courts in CEE countries. The questions, and in particular the underlying values and normative foundations that arise with regard to the constitutional role of the ECB on the hand, and the constitutional, rule of law and democratic backsliding on the other hand, are qualitatively different, so that they also require a different response, including under the paradigm of constitutional pluralism.

The great majority of CJEU cases, perhaps even all of them, which have so far been directed at Hungary and Poland in the context of their ailing constitutional democracy, have touched on the constitutional values and institutions of constitutional democracy whose content leaves very little room for genuine, e.g. legitimate difference in the name of constitutional pluralism. The EU foundational values, proclaimed in Art. 2 TEU: human dignity, freedom, democracy, equality, the rule of law, respect for human rights, including those of minorities, derive from the member states, which have uploaded them on the level of the European Union. These values are, as the member states have explicitly written in the Treaty, shared values, common to the member states. The same is, of course, true of the independence of the judiciary, which has been at the heart of the conflict

\footnotetext{
${ }^{49}$ Avbelj, supra note 34 (drawing on Nicole Roughan, Authorities: Conflicts, Co-Operation and Transnational Legal Theory (2013)).

${ }^{50}$ Vlad Perju, Against Bidimensional Supremacy in EU Constitutionalism, GERMAN L.J. (forthcoming 2020).

${ }^{51}$ Well-ordered in the sense that the conventional standards of Rule of Law and democracy are well established. Not necessarily in the sense promoted by Rawls, see JOHN RAwLS, A THEORY OF JUSTICE 5 (1971).
} 
between the EU and Hungary and Poland. The institutional core of judicial independence is so well established, shared across the Council of Europe, indeed all over the world, that, again, it leaves very little room for a pluralist maneuver. In the case of judicial independence, this room is small enough that it precludes ex-ante the most flagrant tampering with the judiciary that has been witnessed so far, and which therefore simply cannot be subsumed under any meaningful pluralist rationale. In any case, whenever the so-called autocratic member states would want to avail themselves of a pluralist exception to these values they would need to carry a very heavy burden of proof, which they would unlikely be able to dispense with.

If this is so, the argument that the German FCC and the captured constitutional courts of the CEE countries would be treated differently when pluralistically defying the CJEU, as if creating one law for the rich and another for the poor, ${ }^{52}$ loses its strength. The FCC case is simply different and equal treatment not only requires that similar cases are treated similarly, but also that different cases are treated differently. The contested FCC decision neither affects the fundamental values of the Union, nor seeks to defend a 'national' exception to the principle of judicial independence. It hence does not take place in the domain, in which the room for pluralism is small or even inexistent. The FCC pluralist ruling contests the division of competences between the EU and the member states, which has been distorted out of the CJEU's too deferential review of the ECB monetary measures that have, due to the constitutional imbalances inside the Union, excessively born on the fiscal competences currently still reserved for the member states. ${ }^{53}$ The FCC ruling, therefore, does not detract from the fundamental values of the Union, in particular of democracy and the rule of law. To the contrary, it strengthens them. It contributes to the rule of law by (indirectly) demanding from the CJEU a more thorough review of the increasingly powerful EU institutions. But it also adds to the EU democracy, suggesting that fiscal competences, which are at the economic heart of democracy - best expressed through the slogan of no taxation without representation - should be exercised by democratically accountable bodies either on the national or on the supranational level.

The same conclusion, stressing the difference between the 'normal' and 'authoritarian' cases of constitutional pluralism, is reached even if our sample of cases is extended further back to the history and to include not just the German, but also other constitutional courts. Thus the FCC questioning the supremacy of EU law in the Solange saga, at least indirectly, led to the improvement of human rights protection in the European Union. ${ }^{54}$ The FCC Maastricht and Lisbon critique of the democratic insufficiency of the EU, its lack of a clearer division of competences, contributed to the strengthening of the democratic potential of the EU, by building on the potential of EU citizenship; increased competences of the European Parliament; enumeration of different types of competences in the Treaties and prescription of additional principles for their exercise. A similar story could be told about the Italian Constitutional Court and its controlimiti jurisprudence in general, ${ }^{55}$ as well as the Taricco exchange (between the Italian Constitutional Court and the CJEU) in particular. ${ }^{56}$ The latter, thanks to pluralism, strengthened the principle of legality in criminal procedures, not just on the national level, but also as part of the

\footnotetext{
${ }^{52} I d$. at 5 .

${ }^{53}$ Matej Avbelj, The Right Question about the FCC Ultra Vires Decision, VerfassungsBlog, (6 May 2020), https:// verfassungsblog.de/the-right-question-about-the-fcc-ultra-vires-decision/, DOI:https://doi.org/10.17176/20200507-013348-0.

${ }^{54}$ For an overview of evolution of human rights protection in the EU see Matej Avbelj, Human Rights Inflation in the European Union, in The Fragmented Landscape of Fundamental Rights Protection in Europe - The Role of Judicial AND Non-Judicial ACTORS 9 (Lorenza Violini \& Antonia Baraggia eds., 2018).

${ }^{55}$ Marta Cartabia, The Italian Constitutional Court and the Relationship between the Italian Legal System and the European Community, 12 Mich. J. INT'L L. 173 (1990-1991).

${ }^{56}$ Matteo Bonelli, The Taricco Saga and the Consolidation of Judicial Dialogue in the European Union, 25 MAASTRICHT J. EUR. COMP. L. 357 (2018).
} 
EU standards. Along the same lines, the Danish Supreme Court with its resistance to the CJEU in the Ajos case is, ${ }^{57}$ in fact, pushing the CJEU, and indirectly the EU legislature, to provide a statutory legal basis for a prohibition of discrimination on the grounds of age to engender legal effects in Denmark. Only the Czech Landtova decision, due to its exclusively national particularity, ${ }^{58}$ does not seem to be using pluralism in order to contribute to the strengthening of the EU fundamental values and to a more transparent, accountable and also effective relationship between the EU and its member states.

\section{E. Conclusion}

This article has examined the relationship between constitutional pluralism and authoritarianism. This was necessary since the Weiss decision of the FCC spurred unusual attacks on constitutional pluralism, a particular theoretical vision of European integration, describing it as inherently dangerous and demanding its prompt abandonment out of chiefly instrumentalist concerns. That is in order to prevent the use of constitutional pluralism by authoritarian regimes to justify their acts of constitutional, democratic and the rule of law backsliding in their confrontation with the EU, which has been striving to restore these values. We have argued that this critique of constitutional pluralism does not succeed. Due to its truncated, exclusively positivist understanding of constitutional pluralism, it has failed to take into account pluralism's normative core. The latter presents itself an antipode to authoritarianism, which means that autocratic regimes simply cannot credibly avail themselves of the theory of constitutional pluralism to justify their authoritarian actions. This theoretical claim turns even sharper if applied to concrete cases. The fundamental values of the Union and the judicial independence that have come under the most direct attack by the authoritarian regimes, leave very little room for pluralist dissonance and, in any case, raise the bar of justification of pluralist difference so high that it certainly precludes the most flagrant violations of these values. Constitutional pluralism then, neither in theory nor in practice, does not pose a threat for the European Union, even when some of its member states are on the authoritarian course. Pluralism, in fact, demonstrates why these authoritarian tendencies present an illegitimate exercise of authority. On the other hand, the existence and reliance on constitutional pluralism in the course of the history of European integration has in fact strengthened the fundamental values of the Union, contributed to the overall system of national/supranational checks and balances, making the EU an example of an accountable and reflexive system of governance, conducted in a responsive heterarchical rather than hierarchical way, paying respect to the Union's inherent socio-political diversity. Too much, not just of theoretical, but especially of practical importance in the European Union, would be lost if constitutional pluralism was given up for the unsubstantiated, event-driven reasons, as its critics suggest.

\footnotetext{
${ }^{57}$ Mikael Rask Madsen, Henrik Palmer Olsen, \& Urška Šadl, Competing Supremacies and Clashing Institutional Rationalities: the Danish Supreme Court's Decision in the Ajos Case and the National Limits of Judicial Cooperation, 23 EUR. L.J. 140 (2017).

${ }^{58}$ Michal Bobek, Landtová, Holubec, and the Problem of an Uncooperative Court: Implications for the Preliminary Rulings Procedure, 10 Eur. ConsT. L. REv. 54 (2014); Jan Komarek, Czech Constitutional Court Playing with Matches: the Czech Constitutional Court Declares a Judgment of the Court of Justice of the EU Ultra Vires; Judgment of 31 January 2012, Pl. ÚS 5/12, Slovak Pensions XVII, 8 EUR. CONST. L. REV. 323 (2012).
}

Cite this article: Avbelj M (2020). Constitutional Pluralism and Authoritarianism. German Law Journal 21, $1023-1031$. https://doi.org/10.1017/glj.2020.56 